Aburaida, L. M. (2021). Obstacles Facing Rural Women's Development in Palestinian Society: Nablus Governorate as a Case Study

\title{
Obstacles Facing Rural Women's Development in Palestinian Society: Nablus Governorate as a Case Study
}

\author{
Loai Mahmoud Aburaida* \\ An-Najah National University \\ *Corresponding Author: laburaida@najah.edu \\ Received : 2019-08-27 \\ Rev. Req. : 2019-12-10 \\ Accepted : 2020-02-05
}

\begin{abstract}
Women constitute 49 percent of the Palestinian population, but the participation of Palestinian women in economic and social development in Palestinian society is low. The low participation of women is due to many obstacles and constraints preventing them from contributing to the economic and social development of Palestinian society. This study aims to address the most important obstacles facing Palestinian women in achieving development, focusing on the problems and constraints facing rural women in Nablus Governorate. The study used the descriptive, analytical, inductive, and historical approach based on references, books, periodicals, and field work. The data were collected through personal interviews and questionnaires. One hundred questionnaires were distributed to obtain scientific results in an objective manner. The study found that there are a number of factors preventing Palestinian women from contributing to the development process, most importantly social, economic, political, security, media, and personal factors. The study concluded with a number of important recommendations and proposals necessary to increase the role of rural women as well as the economic and social development of Palestinian society.
\end{abstract}

Keywords: Development, Rural Women, Palestinian Women

\section{Introduction}

It is recognized that the participation of Palestinian women in social and economic life in the West Bank is low. Moreover, rural women's activity is still ineffective in rural development (Shteih, 2018). The Palestinian Central Bureau of Statistics shows that 85.4 percent of the women in the West Bank are unemployed (PCBS, 2017a). According to the published report by 
Aburaida, L. M. (2021). Obstacles Facing Rural Women's Development in Palestinian Society: Nablus Governorate as a Case Study

the Palestinian Central Bureau of Statistics, women constituted 49 percent of the Palestinian population in 2019. Palestinian women's participation in the labor force is 21 percent (Awad, 2018). In addition, there is a large gap between the rural and urban communities in Palestine. This leads to the absence of qualified cadres who can lead and develop rural communities.

Based on secondary sources of books, periodicals, and related reports, the study followed the analytical, inductive, historical, and descriptive method. In addition, the study depends on primary sources represented by field data collected through personal interviews and questionnaires. The questionnaires were distributed randomly in Nablus Governorate, targeting 100 Palestinian women ages 15-65.

This study aims at identifying the economic activities practiced by Palestinian rural women and their community participation. It also aims at identifying the most important challenges and constraints facing Palestinian rural women in achieving development. Finally, the study aims to provide opinions, ideas, and proposals for activating Palestinian rural women's roles and performance in society through answering the following questions:

1. What are the social and educational characteristics of rural women?

2. Is there a low participation in the development of Palestinian rural communities? Is this decline due to the vulnerability of rural women?

3. What are the obstacles that prevent rural women from participating in the development of Palestinian rural communities?

4. How can rural women be empowered to play an active role in the Palestinian society and to increase their participation in overall development?

The importance of this research stems from the fact that it studies an important segment of the society. Future generations will depend on this segment to reach a comprehensive and sustainable development in the countryside.

In order to identify the obstacles preventing Palestinian rural women from development in society, it was necessary to know the role of rural women in development. The researcher considered conducting a field study that reflects this reality through a questionnaire designed for this purpose. The questionnaire included questions related to study objectives and to answer study questions from the following aspects:

First: General information about rural women in Nablus Governorate.

Second: Activities practiced by rural women in Nablus Governorate.

Third: Obstacles and restrictions leading to non-participation in various development activities. Fourth: Recommendations and proposals to activate the role of rural women in real development.

\section{Literature Review}


Aburaida, L. M. (2021). Obstacles Facing Rural Women's Development in Palestinian Society: Nablus Governorate as a Case Study

Development is the exploitation of the available energies and possibilities to meet the required needs of community and development in accordance with community, cultural, social, and economic needs. It is a complex process encompassing all life aspects such as economic, social, intellectual, political, and ideological life (Pinot, 1972). Over the past few years, many definitions of development have emerged. One of these defines development as the investment in the development of human resources and development through education and training for members of society to participate positively in the community (Sarhan, 2014).

There have been considerable efforts in rural development that have led to controversy about the starting point in rural development. Is it through achieving awareness or through achieving economic development? Should there be focus and attention on the community or the most vulnerable economic and social sectors in society? What can be done toward patterns of communal injustice? In this context, Gandhi's ideas for rural development are the most important of these ideas in terms of influence and continuity. He is recognized for his emphasis on the fact that change does not come from violence but from persuasion (Hopkins, 1998).

Women have a vital role in development. Their full participation is therefore necessary to achieve sustainable development. Sustainable development is achieved through equality between women and men in rights, opportunities, and responsibilities. Social justice is a precondition in this process (Lohani \& Aburaida, 2017). Rural women have a major role in the development of the rural family. Women work in all social, economic, and political fields. Studies indicate that rural women contribute about four percent of the world's food. In fact, this ratio may reach 80 percent in some developing countries (UNDP, 1990). Studies also show that in many societies, such as in Africa and Asia, women work longer hours than men. Women's weekly work increases by about 13 hours; on the other hand, women work in Eastern European and Latin American countries about 6-7 hours more than men (Sayed, 1996).

It is worth mentioning that international efforts to mainstream the role of women in development have yielded positive results. Grassroots and non-governmental organizations have played an active role in improving women's access to welfare and ease the restrictions related to participation and control (Fonjong, 2001). However, overall rural development in general and the role of Palestinian women in particular have been severely neglected. They have been dismissed out of the economic and social development plans in the era of the Israeli occupation, even after the establishment of the Palestinian Authority in 1994. Despite the high participation of Palestinian women in the labor force during the past years, it is still very low compared with men. Palestinian women's participation rate in the Palestinian labor force was 21.7 percent in 2018, compared with 10.3 percent in 2001 (Figure 1).

Figure 1: Participation in the labor force by women and men 15 years and older in Palestine, 2001-2018 
Aburaida, L. M. (2021). Obstacles Facing Rural Women's Development in Palestinian Society: Nablus Governorate as a Case Study

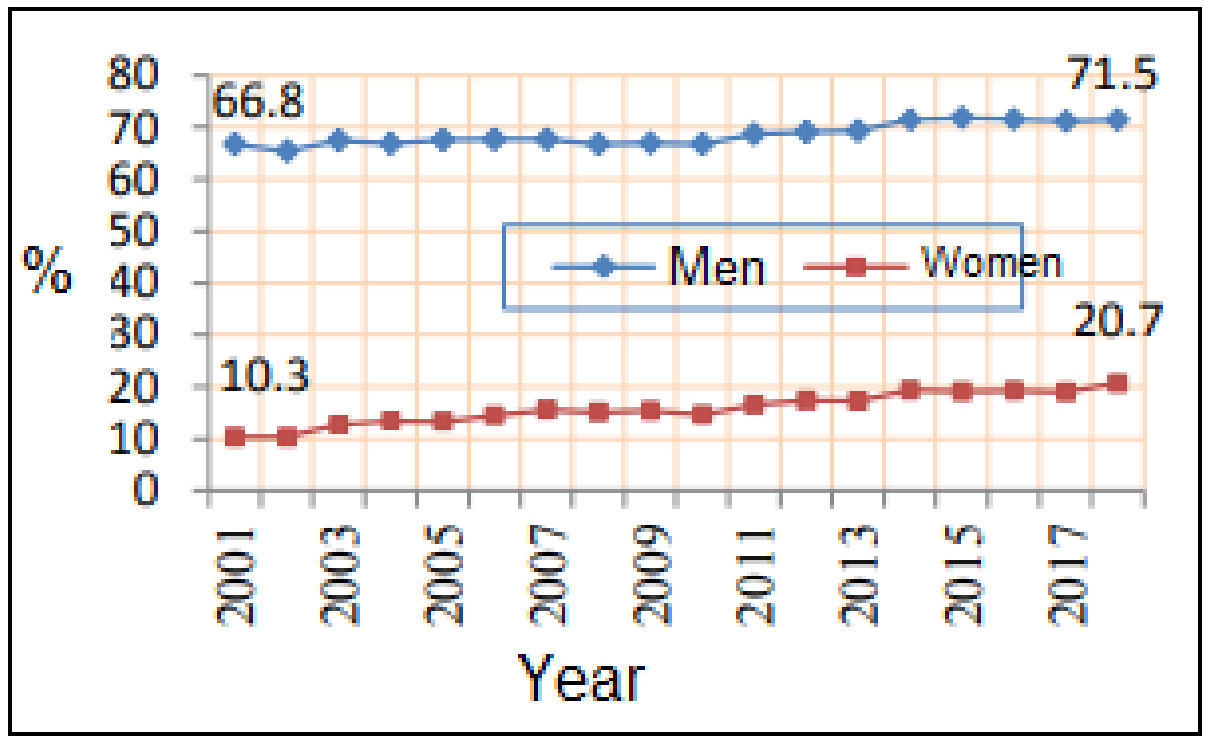

Source: Awad, 2018

As the previous figure shows, women's role in economic and social development is a vital one. Tim and Nadi (2010) studied the extent to which Palestinian women participate in development; their findings show that women have an important role that can only be realized through justice and equality between men and women in society.

Najm (2013) studied Palestinian university youth trends toward women's issues in education and work. The study concluded that youth attitudes are positive toward women's education and work. Hamayel (2003) examined the attitudes of Palestinian university students toward the work of women. The researcher concluded that the society has a positive attitude toward women. It also emphasizes the role of women in economic development within the Palestinian society. On the other hand, Jaber (2005) concluded, in research about obstacles facing Palestinian women working in the public sector in the northern governorates of the West Bank, that the most important obstacles are the Israeli security policies on the checkpoints between the cities and villages of the West Bank. This prevents Palestinian women from reaching their workplaces and delays their return home. The study by Mohamad (2011) found that there is no correlation between the educational curricula and the needs of the society, which leads to a lack of cultural awareness and high unemployment in Palestinian society. In addition, the Palestinian-Israeli conflict and the lack of Palestinian unity have had a significant impact on the limited funding, which is the core of economic activity.

\section{Methodology}

This study crosses both quantitative and qualitative research tools to collect original data, which is analyzed in the framework of a case study methodological approach, studying the development of rural women in Palestinian society and its main constraints under an exploratory inductive approach. This study does not begin with a hypothesis, using instead research questions to narrow the scope of the study. 
Aburaida, L. M. (2021). Obstacles Facing Rural Women's Development in Palestinian Society: Nablus Governorate as a Case Study

The study of the obstacles facing rural women in Palestinian society benefits not only from secondary data such as books, articles, periodicals, and related reports; it also uses original primary data collected through questionnaires and interviews. The questionnaires were designed to obtain scientific results objectively from 100 Palestinian women in Nablus Governorate. The in-depth interviews were conducted with the heads of women's associations, trade union organizations, women workers, and unemployed women.

\section{Dataset}

Nablus Governorate is located in the north of the West Bank, 53 kilometers from Jerusalem. It is located along 35.16 west and 32.13 north of the Equator (Figure 2). It covers an area of 605 square kilometers. Its population is 392,407 . The governorate includes 52 rural communities in addition to the city of Nablus (PCBS, 2017b), according to the administrative division approved by the Palestinian Authority.

Figure 2: Location of the study area

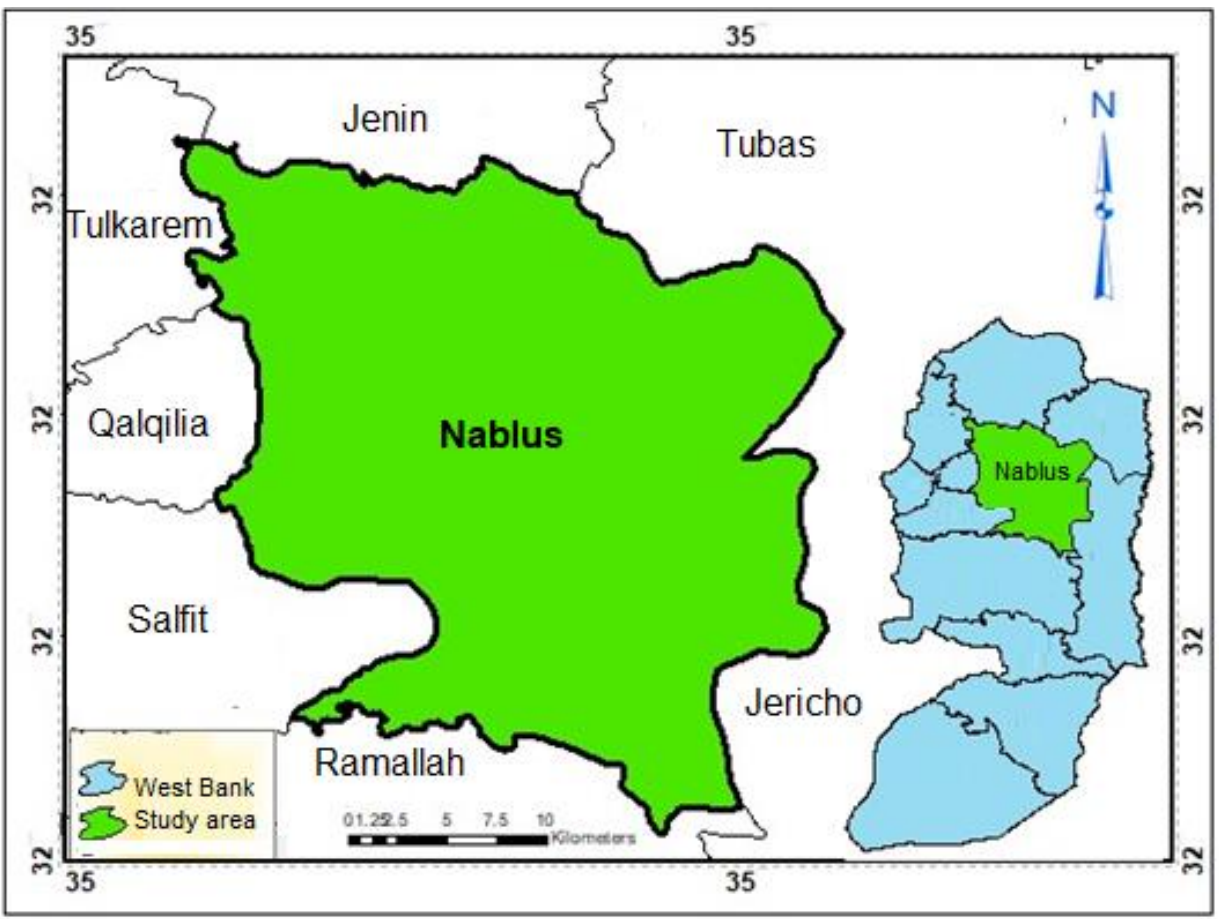

According to PCBS (2017b), Palestinian society is characterized by a young generation; 38.9 percent of the total population in Palestine is under 15 years of age, and 39.1 percent are male and 38.7 percent are female. Youth ages 15-29 make up 29.7 percent of the total population, distributed as 43.9 percent male and 56.1 percent female. 
Aburaida, L. M. (2021). Obstacles Facing Rural Women's Development in Palestinian Society: Nablus Governorate as a Case Study

The sample of this study consists of women in the rural areas in Nablus that contains 64 villages and towns. The questionnaires were distributed randomly to the women in these areas. This sample is characterized by the following characteristics, as shown in Figure 3.

Regarding the age of the sample, looking to Figure 3, it is clear that, on one hand, women aged 15-24 years constitute 40 percent of the population. This is a high percentage that can be relied upon in all future development activities. On the other hand, women aged 25-34 constitute 26 percent, and women aged 35-44 years 13 percent. This is the age at which women can do all developmental activities in society. As for those who are older than 45-65 years, they represent 21 percent; this segment is effective to raise awareness and educate the rural community since they have life experiences.

Figure 3: Age level of sample members

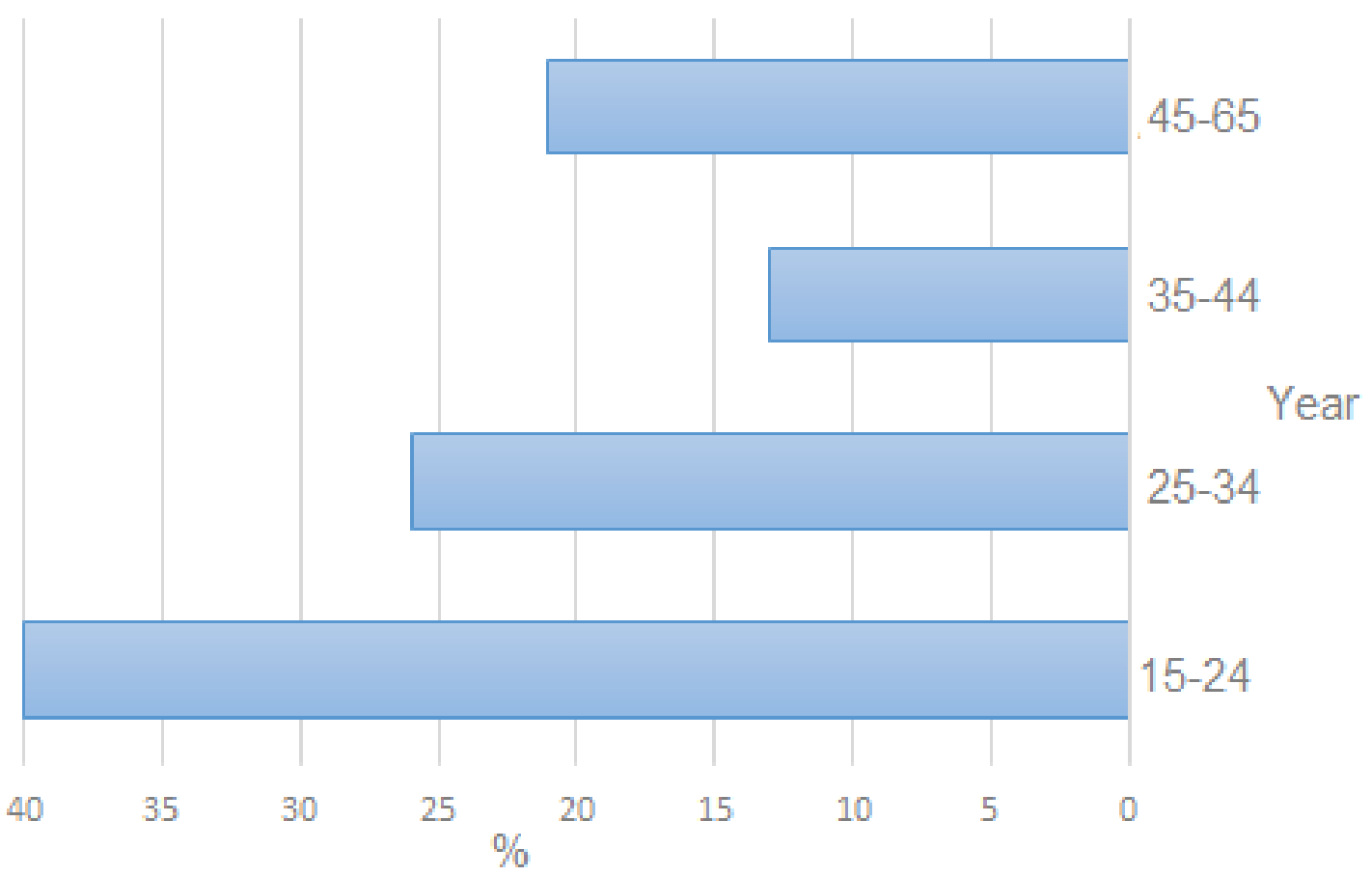

Source: Field Study 2018

Regarding the social status of the sample members, Figure 4 explains that the percentage of single women is 58 percent of the total sample; undoubtedly this has a negative impact on rural women's performance and activity. Rural women's psychological instability, fear of obsession, and the society's attitude regarding spinsterhood are all reasons that expose them to convergence and inability to interact with the surrounding community. It also prevents rural women from carrying out any developmental role. Figure 4 explains also that the percentage of married women is 39 percent. In spite of the fact that married women are more stable psychologically, they are still inactive in performing their role in development. The inability of women to reconcile their home chores and their work or their societal role idles their energies, resulting in the absence of their developmental role. The presence of widows and divorced 
Aburaida, L. M. (2021). Obstacles Facing Rural Women's Development in Palestinian Society: Nablus Governorate as a Case Study

women in the sample of the study was very low: two percent widowed and one percent divorced.

Figure 4: Study sample social status

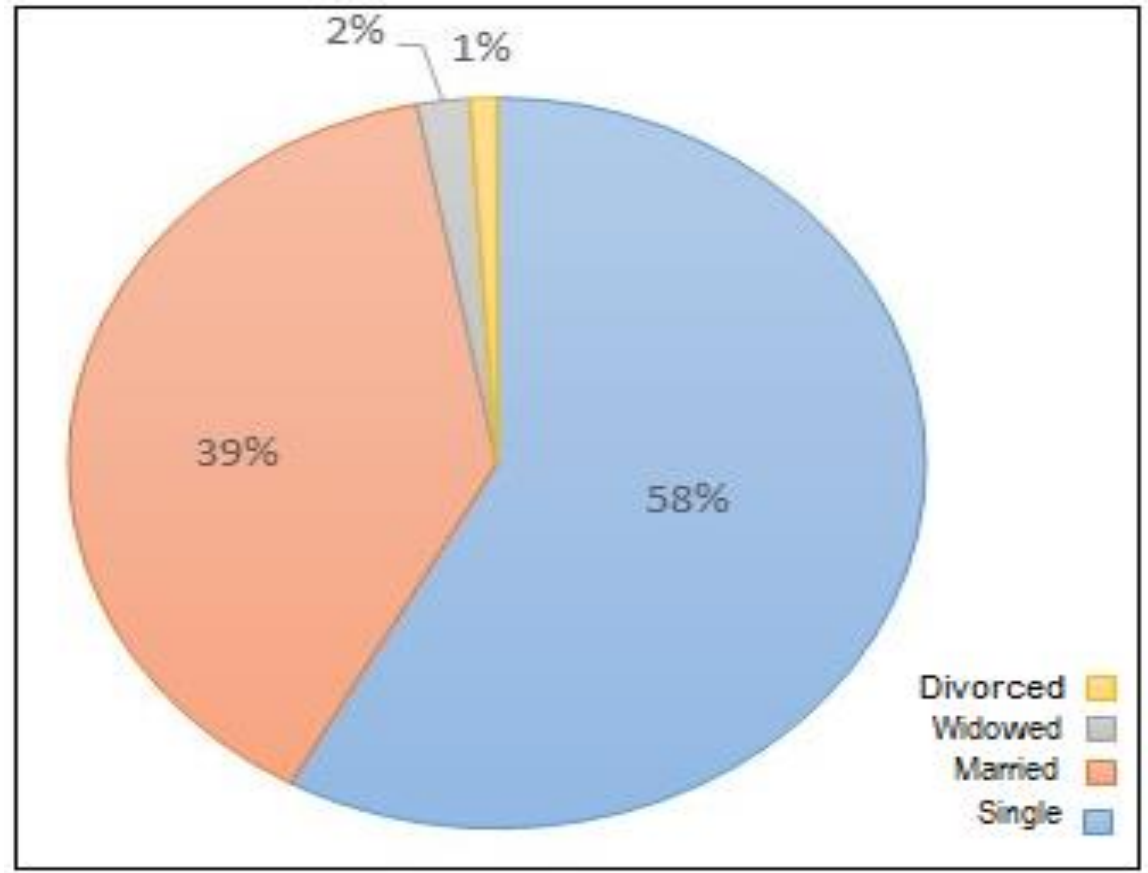

Source: Field Study 2018

Regarding the sample educational level, which is an important factor in the development process: It affects all life aspects and social, economic, and political levels. The low level of women's education in many societies is considered the general factor of underdevelopment and backwardness of society. This study shows that the educational level of rural women is one of the most important pillars in developing the society. Through these educated rural women, we can promote active participation in society. The percentage of those with a university degree was 59 percent, with one percent of them holding a high degree. On the other hand, women in the secondary school and those who attained this degree reached 39 percent. This is a clear indicator of rural women's interest in education, especially after they moved from this stage to the university level; thus, their role contributes effectively in the future development.

\section{Findings}

Despite rural women's high level of education, their participation in economic activities is still very low. The percentage of female workers in the study sample was 6.3 percent, which is less than the percentage of women working in Palestine, 9.7 percent (Shteih, 2018). The study finds that the professions practiced by rural women in the countryside are still limited to traditional occupations. About 29 percent are engaged in handicrafts such as sewing and embroidery, while 26 percent work in agriculture; 23 percent work in education, and the rest work in 
Aburaida, L. M. (2021). Obstacles Facing Rural Women's Development in Palestinian Society: Nablus Governorate as a Case Study

economic activities and social work such as literacy, charities, women's groups, rehabilitation centers, trade unions, etc. The study showed that 12 percent of the respondents were active in their societies, and this is a low percentage that hinders development.

The study showed that there are many obstacles facing rural women in the Palestinian society development process. This includes social, economic, and political aspects, in addition to the lack of training and the institution and the women's collective form (Figure 5).

Figure 5: The most important obstacles facing rural women in the development of the Palestinian society

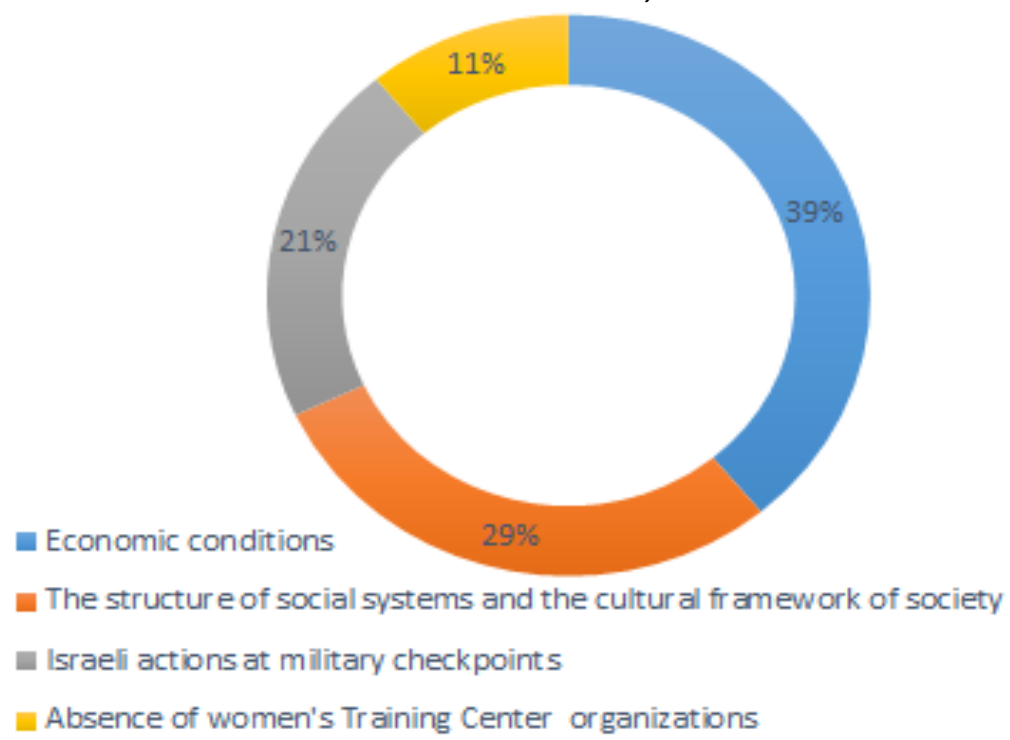

\section{Economic conditions}

The researcher found that the Palestinian-Israeli conflict and the lack of Palestinian unity had a great impact on the limited funding, which is considered the mainstay of economic activity. Of the respondents, 39 percent attribute the prevailing economic conditions not only to the study area but to Palestinian women, which impedes the role of women in development, resulting from the lack of funding for development projects and the spread of poverty in these rural communities. Additionally, 35 percent of respondents said that there is a lack of services in rural areas, which leads to women's reluctance to interact in development work.

The structure of social systems and the cultural framework of society

Economic life revolves around economic, social and political organizations in addition to the cultural framework of society (values, barriers, traditions, beliefs, moral qualities, attitudes, etc.). The existing framework indirectly affects women's role in economic development. It also affects the level of comprehensive development (Abdul-Rahman, 2003). The study explains that 
Aburaida, L. M. (2021). Obstacles Facing Rural Women's Development in Palestinian Society: Nablus Governorate as a Case Study

reducing the role of women in development due to the contribution of the existing structure of social systems and the cultural framework of society is 29 percent. It should be noted that the dominant culture among women plays an important role in hindering their contribution to the overall development. The study revealed that 27 percent of women direct their available savings in many non-productive investments that do not benefit the beneficiary. Their saving is directed toward agriculture, gold hoarding, and acquisition of ornaments. In addition, cultural values and traditions result in spending on many consuming aspects, which do not contribute positively to raising the level of material well-being of individuals and thus impede the role of women in development.

The social systems, customs, and traditions prevailing in rural communities, lack of local council confidence among rural women, and social oppression all lead to the reluctance of rural women to participate in the various development activities. As a result, the study showed that 52 percent of the study sample believes that society does not give rural women the right of decision-making. This leads to imbalance, mistrust, and a permanent conflict between society and ambitions, and exposes rural women to the intransigence and inability to interact with the surrounding society.

\section{Israeli actions at military checkpoints}

The Israeli measures at the military checkpoints are the most important obstacles that prevent Palestinian women from taking part in their developmental role. These checkpoints, which are described by Palestinians as death gates, were increased to hundreds after the intifada in 2000. They are spread throughout the West Bank. Israel military checkpoints are spread along the entrances to cities and towns. Due to this abuse and humiliation, the lives of Palestinian citizens are very difficult. They are subjected to barriers in addition to the killings and arrests that take place at these checkpoints. Palestinians are no safer or freer when they pass a checkpoint. This is directly reflected on Palestinian women, who are afraid of passing through these barriers. Moreover, they are always late at work or in returning home, resulting in staying at home and waiting for a nearby job to avoid passing through these military barriers, which negatively affects and limits their role in development.

\section{Absence of women's training center organizations}

In spite of the increased percentage of education in rural communities, 42 percent of the respondent's members indicated that the lack of training centers and lack of women's organizations isolated rural women from their role in development; 11 percent mentioned that the absence of training and rehabilitation associations for rural women and the lack of women's societies in rural society is one of the important reasons that causes the absence of women from development roles. In addition, undermining rural women in administrative structures and local councils is one of the crucial aspects that led to rural women's reluctance to interact in the development work. 
Aburaida, L. M. (2021). Obstacles Facing Rural Women's Development in Palestinian Society: Nablus Governorate as a Case Study

Rural women are the main drivers of development, but limited access to credit, health care, and education are among the many challenges women face. This crisis is compounded by the global food and economic crisis and climate change. Therefore, empowerment is necessary, not only for the well-being of individuals, families, and rural communities, but also for overall economic productivity since the presence of women in the agricultural labor force is worldwide.

\section{Conclusions and Recommendations}

Rural women have a significant and effective impact on the real development of rural society. They also play a catalytic role in achieving the economic, environmental, and social transformations that are necessary to achieve sustainable development. However, women in these societies are still unable to play a real and active role due to their social conditions and the clear discrimination against rural women. Lack of awareness, training, and rehabilitation, lack of qualified communities for qualified personnel, the absence of women's institutions, the weak role of government in rural areas, and the lack of service accessibility are all reasons for underdevelopment, as well as the lack of economic potential of rural communities and rural women where they do not have direct income, which prevents investment and makes them non-productive and consuming. Empowerment of rural women is therefore critical, not only for the welfare of individuals, families, and communities, but also for overall economic productivity due to the presence of rural women in the workforce throughout the world.

The researcher, through the field study on the obstacles facing rural women in achieving development in Palestinian society, concluded with the following recommendations to activate the role of rural women to achieve real development within its society:

- Promote the educational role of rural women to enable them to gain access to education that ensures equality and parity with men.

- Work on improving and adjusting the image of rural women, combating stereotypical and mental concepts prevailing in the Palestinian society that consider women as housewives doing agricultural work only. All creative areas for rural women must be highlighted.

- Conduct scientific studies on rural women in all aspects to identify needs and develop plans and programs to improve the efficiency of rural women, and liberate them from the economic and social controls imposed on them. It is also necessary to establish a training center in rural areas to serve rural women and raise their scientific and professional efficiency.

- Establish civil associations to eliminate illiteracy and introduce women to their rights in order to achieve their role in the development process.

- Work to improve the image of women in Palestinian society in the media. Also, combat concepts and vulgar images that lead to discrimination against women. Support their work as a fundamental right to contribute to development.

Activating the role of women within the family in the process of social upbringing has a great impact on the comprehensive development of society. It also has an effective role in eliminating 
Aburaida, L. M. (2021). Obstacles Facing Rural Women's Development in Palestinian Society: Nablus Governorate as a Case Study

the negative social phenomena that limit the ability and contribution of women in development such as education, early marriage, and frequent reproduction, etc., in addition to raising the level of women's participation in public, political, and developmental life through their participation in decision-making.

The underdevelopment of societies is due to the backwardness of their cultures. Therefore, it is necessary to create an effective and positive cultural balance. It is also important to liquidate the negative residues, including the details of the daily lives of individuals in the society, so that the continuous exchange between the individual's effective behavior and lifestyle achieves individual autonomy and active participation in society.

\section{References}

Abdul-Rahman, A. (2003). Development management: Development management in the Arab world and the new world order. Kingdom of Saudi Arabia: Center for Arab Unity Studies.

Awad, P. (2018). The situation of Palestinian women. Ramallah: Palestinian Central Bureau of Statistics.

Fonjong, L. (2001). Fostering women's participation in development through nongovernmental efforts in Cameroon. Geographical Journal, 167(3), 223-234.

Hamayel, S. (2003). Palestinian university students' attitudes towards the work of women. Nablus: An-Najah National University.

Hopkins, N. (1998). Gandhi and the discourse of rural development in independent India. Journal of Comparative Poetics, 18, 205-236.

Jaber, D. (2005). Difficulties facing Palestinian women working in the public sector in the northern governorates of the West Bank. Nablus: An-Najah National University.

Lohani, M., \& Aburaida, L. (2017). Women empowerment: A key to sustainable development. The Social ION, 6(2), 26-29.

Mohamad, Y. (2011). The obstacles to development in Palestine. Khartoum: Sudan University of Science and Technology, Institute of Family and Community Development.

Najm, M. (2013). Palestinian university youth attitudes towards women's education and work. IUG Journal of Educational and Psychological Studies, 21(1), 567-617.

PCBS. (2017a). Preliminary results of the general census of population, housing and establishments. Ramallah: Palestinian Central Bureau of Statistics. 
Aburaida, L. M. (2021). Obstacles Facing Rural Women's Development in Palestinian Society: Nablus Governorate as a Case Study

PCBS. (2017b). Women and men in Palestine issues and statistics. Ramallah: Palestinian Central Bureau of Statistics

Pinot, E. (1972). What is development? Beirut: Dar Alhaqiqa.

Sarhan, H. (2014). Sustainable human development and building a knowledge society. Ahl alBayt Journal, 1(16), 138-155.

Sayed, P. (1996). Impact of the WTO agreement on agriculture on the role of women in rural development. Yemen: Ministry of Agriculture.

Shteih, A. (2018). Problems of women in the economic life and the labor market in the West Bank, according to the data of the Palestinian labor force 2015. Nablus: An-Najah National University, unpublished thesis.

Tim, H., \& Anadi, E. (2010). The degree of Palestinian women's participation in development from the perspective of graduate students at An-Najah National University in Nablus. Nablus: An-Najah National University.

UNDP. (1990). Rural women's participation in development. New York, NY: UNDP. 